\title{
Contribution to the chemical composition of minerals of the mimetite-pyromorphite series from the Guatomo mine near Tham Thalu, Bannang Sata District, Yala Province (Thailand)
}

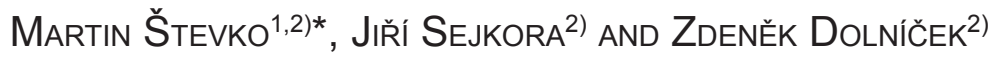 \\ 1)Earth Science Institute, Slovak Academy of Sciences, Dúbravská cesta 9, 84005 Bratislava, Slovak Republic, \\ *e-mail: martin.stevko@savba.sk \\ 2)Department of Mineralogy and Petrology, National Museum, Cirkusová 1740, 19300 Praha 9 - Horní Počernice, \\ Czech Republic
}

ŠTEVKo M, SEJKORA J, DolničEK Z (2020) Contribution to the chemical composition of minerals of the mimetite-pyromorphite series from the Guatomo mine near Tham Thalu, Bannang Sata District, Yala Province (Thailand). Bull Mineral Petrolog 28(2): 237-245 ISSN: 2370-7337

\begin{abstract}
The Guatomo mine is considered as one of the classic localities of mimetite worldwide. The chemical composition of six samples of minerals of mimetite-pyromorphite series from the Guatomo mine, representing different morphologies, colours as well as various geological environments/host rocks, was studied in detail by EMPA-WDS. This study revealed that both mimetite as well as pyromorphite are present at the Guatomo mine, representing rather variable compositional series ranging from the nearly end member mimetite (sample M1 - up to 0.03 apfu of $P$, sample M4 - up to 0.23 apfu of $\mathrm{P}$ and sample M5 with up to 0.18 apfu of $\mathrm{P}$ ), through P-enriched mimetite (with 0.38 apfu of $\mathrm{P}$ ) and As-rich pyromorphite (with 0.82 apfu of As, sample M2) up to As-enriched pyromorphite (sample M3 with As content reaching up to 1.03 apfu and sample M6 with up to 0.80 apfu of As). Besides of $\mathrm{Pb}, \mathrm{As}, \mathrm{P}$ and $\mathrm{Cl}$ only negligible amounts of $\mathrm{Ca}$, $\mathrm{V}$ and $\mathrm{S}$ were detected in studied samples.
\end{abstract}

Key words: mimetite, pyromorphite, supergene minerals, chemical composition, Guatomo mine, Tham Thalu, Thailand

Received: 11. 9. 2020; accepted 7. 11. 2020

\section{Introduction}

The Guatomo lead-tin mine in southern Thailand is together with Johanngeorgenstadt in Germany, Dry Gill during the detailed geological mapping of the mine site in May/June 2019. mine in UK, Tsumeb in Namibia, Ojuela mine or San Pedro Corralitos in Mexico, Endeavor and Mount Bonnie mine in Australia or Pingtouling mine in China one of the few sources of truly world-class quality specimens of mimetite. Very little was known about this locality as a source of fine mineral specimens before the late 1990s when Italian mineral collectors Marco P. Sacchi and Danilo Bernasconi visited this mine and collected several hundreds of excellent mimetite specimens (Bode 1998; Sacchi 2017). Sacchi (2017) described several different styles of minerals of the mimetite-pyromorphite series from the Guatomo mine (e.g. yellow to orange prismatic crystals, hoppered crystals or deep orange botryoidal campylite-like aggregates), all of them tentatively identified as mimetite.

In this short paper, we present new data on chemical composition of various morphological varieties of minerals of the mimetitepyromorphite series from the Guatomo mine, which were collected by the first author (MŠ)

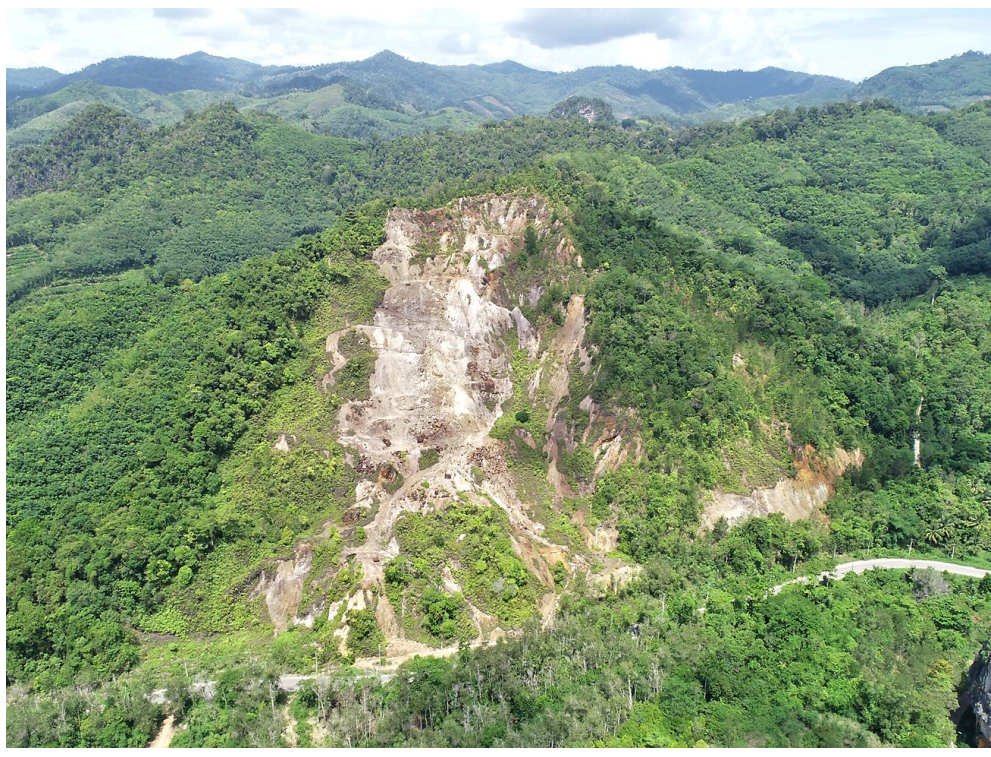

Fig. 1 Aerial drone photo of the Guatomo mine open pit. White areas are weathered granite and brown spots are blocks or remaining unmined parts of gossan. Photo by T. Kijbamrung. 


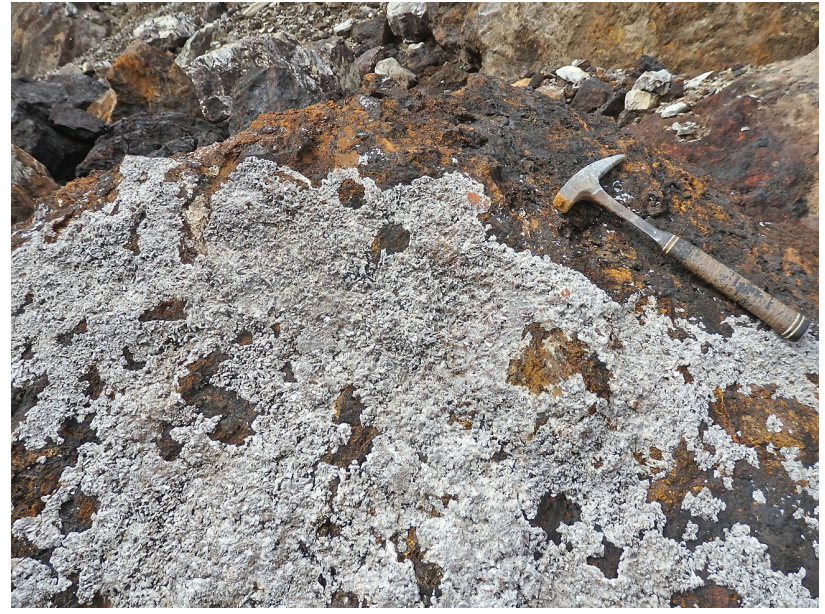

Fig. 2 Fracture plane in limonitic gossan covered with aggregates of white cerussite crystals. Field of view is $100 \mathrm{~cm}$. Photo by M. Števko.

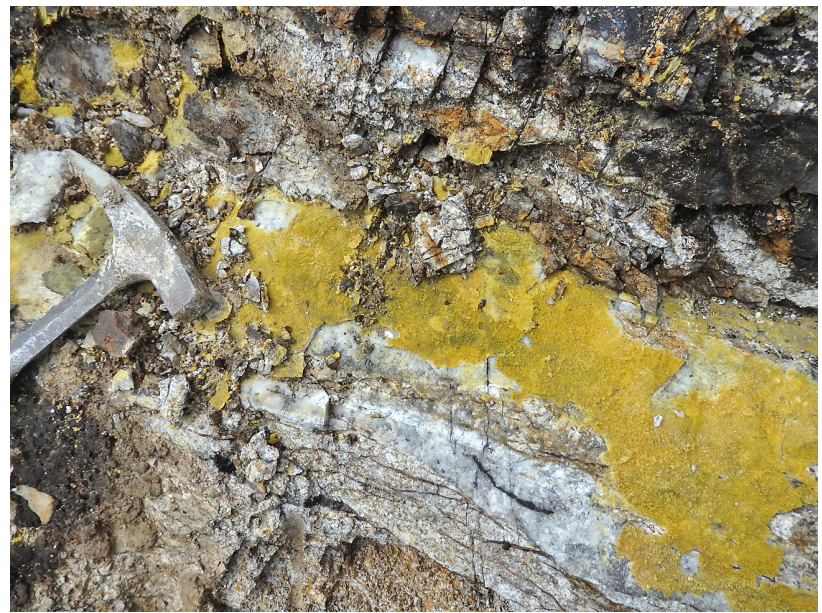

Fig. 3 Detail on subhorizontal vein of hydrothermal quartz with minor cassiterite crosscutting altered granites. Supergene mineralization represented by abundant minerals of the mimetite-pyromorphite series (sample M2) is developed in fractures of quartz vein as well as in fractures of adjacent altered granite. Field of view is $40 \mathrm{~cm}$. Photo by M. Števko.

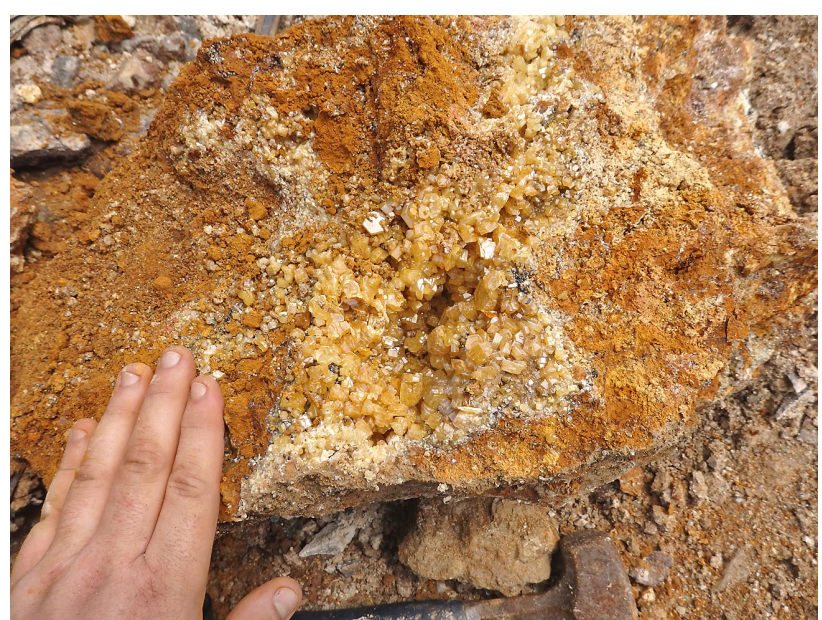

Fig. 4 Block of brownish limonitic gossan with pockets filled with crystals of minerals of the mimetite-pyromorphite series (sample M5). Field of view is $40 \mathrm{~cm}$. Photo by M. Števko.

\section{Geological setting and occurrence}

The Guatomo mine is located next to the Buddhist temple Wat Tham Thalu, around $10 \mathrm{~km}$ west of Bannang Sata town, Yala Province, southern Thailand close to the border with Malaysia. GPS coordinates of the Guatomo mine are: $6^{\circ} 15^{\prime} 26.54^{\prime \prime} \mathrm{N}$ and $101^{\circ} 9^{\prime} 53.12^{\prime \prime} \mathrm{E}$.

The Guatomo lead-tin mine also known as Tham Thalu mine or The Great mine was considered in 1880s as one of the richest ore deposits in the Thai-Malay Peninsula (King 2007). The deposit was primarily exploited by open-pit method (Fig. 1) with some minor exploration shafts and adits (Brown et al. 1951; Goodwin, Vimolset 1981; Sacchi 2017). Monthly production of low-grade Sn concentrate in early 1980 s was 5 to 30 tons. The concentrate also contained up to $37 \%$ of cerussite and $\mathrm{Pb}-\mathrm{Sn}$ alloy was produced during smelting (Goodwin, Vimolset 1981; Suthakorn 1992; Whitbread-Abrutat et al. 1999; Ridd et al. 2011). Mining ceased in 1985 after the collapse of world tin prices (Natchakunlasap 2004). The Guatomo/Tham Thalu deposit is skarn type $\mathrm{Pb}-\mathrm{Sn}$ deposit. Skarn orebodies are developed at the contact zone between intrusion of Jurassic-Triassic porphyritic biotite-rich granite and Permian Ratburi limestone, with extensive supergene zone/gossan developed at the subsurface parts of orebodies. The dominant primary minerals are magnetite, garnets, cassiterite, arsenopyrite and pyrite. Galena was mostly completely replaced by cerussite or minor anglesite and goethite is principal mineral in gossan (Goodwin, Vimolset 1981; Suthakorn 1992; Whitbread-Abrutat et al. 1999; Malaysian-Thai Working group 2009; Ridd et al. 2011). Sacchi (2017) in addition to frequent mimetite described also other supergene minerals including carminite, cesàrolite, philipsbornite, plattnerite and segnitite.

Supergene lead mineralization is common at the Guatomo mine and is represented predominantly by cerussite and minerals of the mimetite-pyromophite series. Cerussite occurs either as clusters of white, prismatic and acicular crystals up to $3 \mathrm{~cm}$ or reticulated aggregates which covers areas up to several square meters in fractures of altered granite, hydrothermal quartz veins or gossan (Fig. 2). Nice white or pale yellowish-green groups of cerussite snowflakes up to $4 \mathrm{~cm}$ or pods of massive black to grey cerussite up to $50 \mathrm{~kg}$ were also observed. Minerals of the mimetite-pyromorphite series are common in fissures of hydrothermally altered granites, in fractures of hydrothermal quartz veins crosscutting altered granites (Fig. 3 ) as well as in pockets and fractures in yellowish-brown to black limonitic gossan (Fig. 4). Samples were collected at the various parts of the Guatomo mine open pit from the all above mentioned geological environments with emphasis on morphological varieties of minerals of the mimetite-pyromorphite series. Anglesite is rare and it forms colourless to white, prismatic or pyramidal crystals up to $1 \mathrm{~cm}$ in gossan often replaced by goethite. Minerals of philipsbornite-segnitite series occur as microcrystalline coatings frequently directly associated with minerals of the mimetite-pyromorphite series. Pale blue to yellowish-green pseudomorphs after crystals of mimetite have been also found. Plattnerite is rare as black prismatic microcrystals resting on aggregates of minerals of the mimetite-pyromorphite series. Rare microcrystalline coatings of malachite and linarite were observed mostly in fragments of gossan on the base of the open pit. 


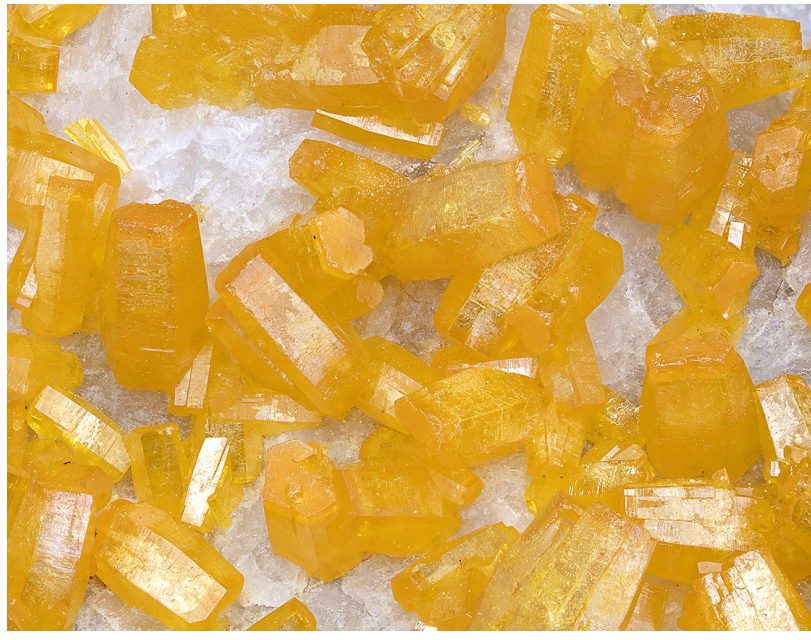

Fig. 5 Prismatic crystals of mimetite resting on quartz matrix (sample M1). Field of view is $10 \mathrm{~mm}$. Photo by P. Škácha.

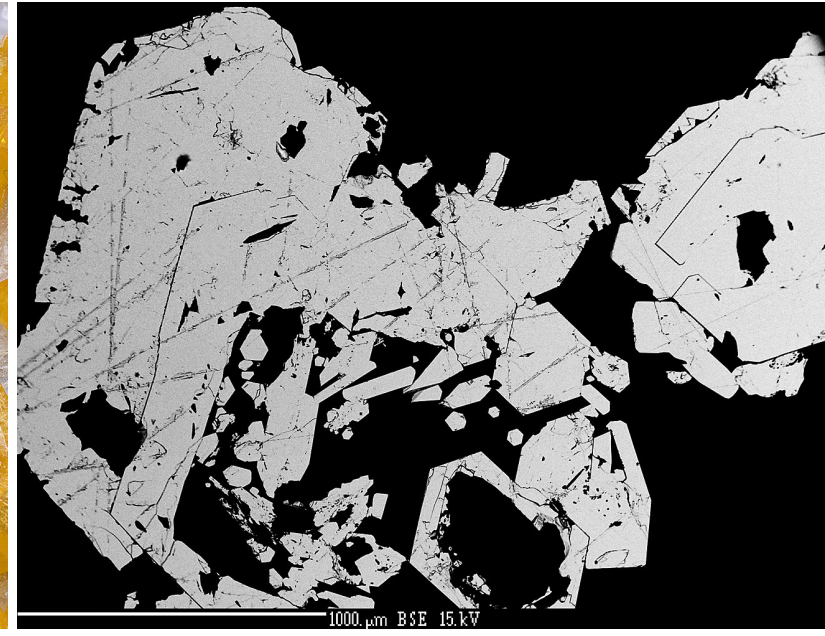

Fig. 6 Cross-section through chemically homogenous crystals of mimetite (sample M1). BSE image by Z. Dolníček.

Table 1 Chemical composition of sample M1 (wt.\%).

\begin{tabular}{lrrrrrrrrrrr}
\hline & mean & 1 & 2 & 3 & 4 & 5 & 6 & 7 & 8 & 9 & 10 \\
\hline $\mathrm{CaO}$ & 0.02 & 0.03 & 0.00 & 0.05 & 0.00 & 0.00 & 0.00 & 0.00 & 0.00 & 0.05 & 0.03 \\
$\mathrm{PbO}$ & 75.23 & 75.50 & 74.98 & 75.33 & 75.15 & 74.39 & 75.21 & 75.33 & 75.43 & 75.42 & 75.59 \\
$\mathrm{P}_{2} \mathrm{O}_{5}$ & 0.02 & 0.00 & 0.03 & 0.00 & 0.00 & 0.00 & 0.02 & 0.13 & 0.05 & 0.00 & 0.02 \\
$\mathrm{As}_{2} \mathrm{O}_{5}$ & 21.99 & 22.64 & 21.89 & 22.44 & 21.99 & 22.17 & 22.35 & 21.62 & 21.68 & 21.42 & 21.74 \\
$\mathrm{~V}_{2} \mathrm{O}_{5}$ & 0.01 & 0.00 & 0.00 & 0.00 & 0.09 & 0.00 & 0.00 & 0.06 & 0.00 & 0.00 & 0.00 \\
$\mathrm{SO}_{3}$ & 0.05 & 0.00 & 0.04 & 0.00 & 0.00 & 0.04 & 0.00 & 0.11 & 0.05 & 0.09 & 0.16 \\
$\mathrm{Cl}$ & 2.63 & 2.75 & 2.71 & 2.61 & 2.77 & 2.45 & 2.74 & 2.67 & 2.67 & 2.53 & 2.41 \\
$\mathrm{O}=\mathrm{Cl}$ & -0.59 & -0.62 & -0.61 & -0.59 & -0.63 & -0.55 & -0.62 & -0.60 & -0.60 & -0.57 & -0.54 \\
\hline total & 99.37 & 100.30 & 99.03 & 99.85 & 99.37 & 98.50 & 99.71 & 99.32 & 99.28 & 98.94 & 99.41 \\
\hline $\mathrm{Ca}^{2+}$ & 0.004 & 0.008 & 0.000 & 0.014 & 0.000 & 0.000 & 0.000 & 0.000 & 0.000 & 0.014 & 0.008 \\
$\mathrm{~Pb}^{2+}$ & 5.253 & 5.151 & 5.266 & 5.185 & 5.253 & 5.168 & 5.190 & 5.275 & 5.337 & 5.406 & 5.308 \\
\hline$\Sigma$ & 5.257 & 5.159 & 5.266 & 5.198 & 5.253 & 5.168 & 5.190 & 5.275 & 5.337 & 5.421 & 5.316 \\
\hline $\mathrm{P}^{5+}$ & 0.005 & 0.000 & 0.007 & 0.000 & 0.000 & 0.000 & 0.004 & 0.028 & 0.011 & 0.000 & 0.004 \\
$\mathrm{As}^{5+}$ & 2.983 & 3.000 & 2.986 & 3.000 & 2.985 & 2.992 & 2.996 & 2.940 & 2.979 & 2.982 & 2.965 \\
$\mathrm{~V}^{5+}$ & 0.003 & 0.000 & 0.000 & 0.000 & 0.015 & 0.000 & 0.000 & 0.010 & 0.000 & 0.000 & 0.000 \\
$\mathrm{~S}^{6+}$ & 0.009 & 0.000 & 0.008 & 0.000 & 0.000 & 0.008 & 0.000 & 0.021 & 0.010 & 0.018 & 0.031 \\
\hline$\Sigma$ & 3.000 & 3.000 & 3.000 & 3.000 & 3.000 & 3.000 & 3.000 & 3.000 & 3.000 & 3.000 & 3.000 \\
\hline $\mathrm{Cl}^{-}$ & 1.157 & 1.181 & 1.199 & 1.132 & 1.219 & 1.073 & 1.191 & 1.178 & 1.190 & 1.143 & 1.067 \\
\hline mean - average of 10 analyses; calculated empirical formulas are based on sum of (As+P+V+S) $=3$ apfu
\end{tabular}

mean - average of 10 analyses; calculated empirical formulas are based on sum of $(A s+P+V+S)=3$ apfu

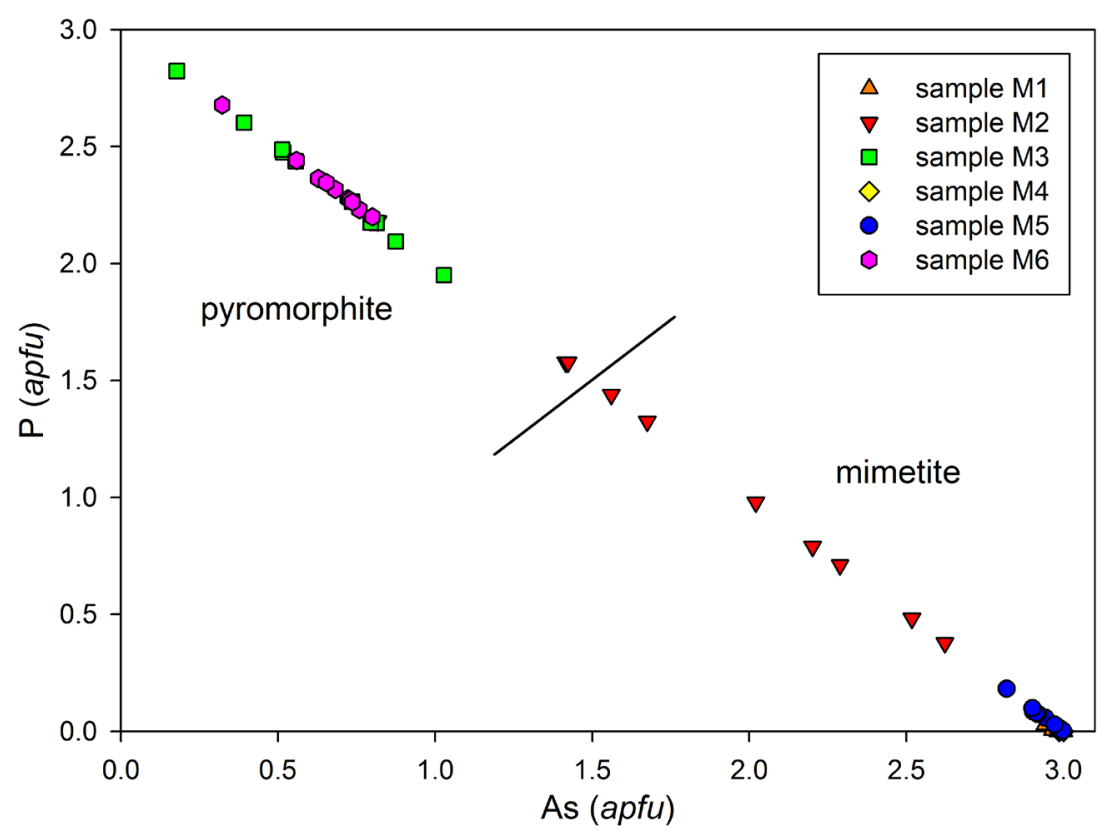

Fig. 7 Variation of $P$ and As (apfu) in minerals of mimetite-pyromorphite series from the Guatomo mine. 


\section{Analytical methods}

The chemical analyses of minerals of the mimetite-pyromorphite series were performed using a Cameca SX100 electron microprobe (Department of Mineralogy and Petrology, National Museum, Prague, Czech Republic) operating in the wave-dispersive (WDS) mode ( $15 \mathrm{kV}, 20 \mathrm{nA}$ and $3 \mu \mathrm{m}$ wide beam). The following standards and X-ray lines were used to minimize line over-
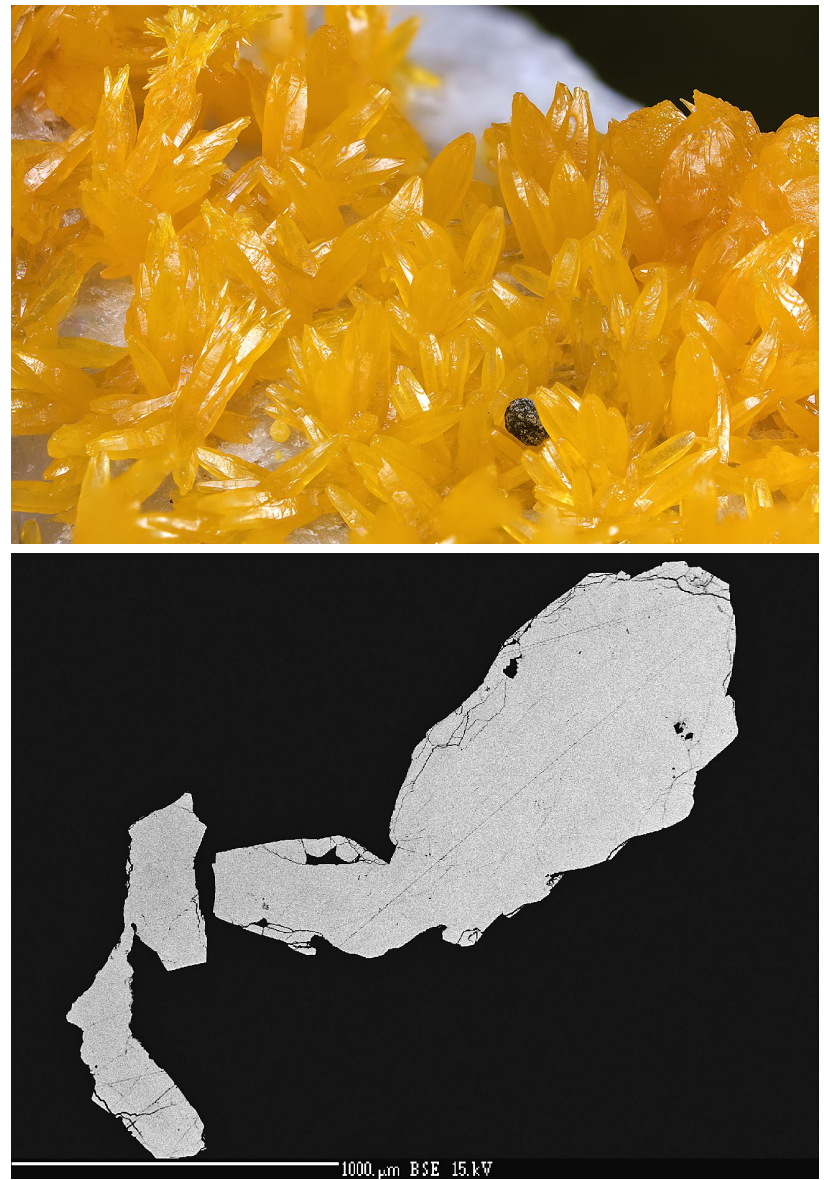

laps: albite (NaKa), apatite (CaKa, PKa), baryte (BaL $\alpha)$, $\mathrm{Bi}(\mathrm{BiM} \alpha)$, celestine (SrL $\beta, \mathrm{SK} \alpha)$, clinoclase (AsL $\alpha)$, Co (CoKa), $\mathrm{Cr}_{2} \mathrm{O}_{3}(\mathrm{CrK \alpha}), \mathrm{CuFeS}_{2}$ (CuKa, SKa), diopside (MgKa), halite (CIKa), hematite (FeKa), LIF (FKa), rhodonite (MnKa), sanidine (AlKa, KKa, SiKa), scheelite $(\mathrm{WL} \alpha)$, vanadinite $(\mathrm{VK} \alpha)$, wulfenite $(\mathrm{PbM \alpha}, \mathrm{MoL} \alpha)$ and $\mathrm{ZnO}(\mathrm{ZnKa})$. Contents of the above-listed elements, which are not included in the tables, were analysed

Table 2 Chemical composition of sample M2 (wt.\%).

\begin{tabular}{lrrrrrrrrrrr}
\hline & mean & 1 & 2 & 3 & 4 & 5 & 6 & 7 & 8 & 9 & 10 \\
\hline $\mathrm{CaO}$ & 0.03 & 0.03 & 0.03 & 0.05 & 0.07 & 0.04 & 0.03 & 0.00 & 0.00 & 0.03 & 0.04 \\
$\mathrm{PbO}$ & 77.27 & 78.15 & 75.49 & 75.60 & 79.54 & 75.31 & 78.39 & 76.19 & 78.55 & 77.18 & 78.25 \\
$\mathrm{P}_{2} \mathrm{O}_{5}$ & 5.64 & 7.04 & 2.24 & 3.32 & 10.94 & 1.75 & 8.03 & 3.81 & 8.02 & 4.70 & 6.60 \\
$\mathrm{As}_{2} \mathrm{O}_{5}$ & 14.47 & 12.37 & 18.94 & 17.32 & 6.65 & 19.61 & 11.67 & 17.17 & 11.71 & 15.70 & 13.51 \\
$\mathrm{~V}_{2} \mathrm{O}_{5}$ & 0.00 & 0.00 & 0.00 & 0.00 & 0.00 & 0.00 & 0.00 & 0.05 & 0.00 & 0.00 & 0.00 \\
$\mathrm{SO}_{3}$ & 0.00 & 0.00 & 0.00 & 0.00 & 0.00 & 0.00 & 0.04 & 0.00 & 0.00 & 0.00 & 0.00 \\
$\mathrm{Cl}$ & 2.65 & 2.70 & 2.47 & 2.45 & 2.85 & 2.58 & 2.86 & 2.63 & 2.63 & 2.62 & 2.70 \\
$\mathrm{O}=\mathrm{Cl}$ & -0.60 & -0.61 & -0.56 & -0.55 & -0.64 & -0.58 & -0.64 & -0.59 & -0.59 & -0.59 & -0.61 \\
\hline total & 99.47 & 99.69 & 98.61 & 98.19 & 99.41 & 98.70 & 100.37 & 99.26 & 100.31 & 99.65 & 100.49 \\
\hline $\mathrm{Ca}^{2+}$ & 0.008 & 0.008 & 0.008 & 0.013 & 0.018 & 0.011 & 0.007 & 0.000 & 0.000 & 0.008 & 0.010 \\
$\mathrm{~Pb}^{2+}$ & 5.053 & 5.077 & 5.166 & 5.143 & 5.043 & 5.184 & 4.898 & 5.028 & 4.915 & 5.113 & 4.996 \\
\hline$\Sigma$ & 5.062 & 5.085 & 5.174 & 5.157 & 5.060 & 5.194 & 4.906 & 5.028 & 4.915 & 5.120 & 5.006 \\
\hline $\mathrm{P}^{5+}$ & 1.161 & 1.439 & 0.483 & 0.711 & 2.182 & 0.378 & 1.577 & 0.791 & 1.577 & 0.980 & 1.325 \\
$\mathrm{As}^{5+}$ & 1.837 & 1.561 & 2.517 & 2.289 & 0.818 & 2.622 & 1.416 & 2.201 & 1.423 & 2.020 & 1.675 \\
$\mathrm{~V}^{5+}$ & 0.001 & 0.000 & 0.000 & 0.000 & 0.000 & 0.000 & 0.000 & 0.008 & 0.000 & 0.000 & 0.000 \\
$\mathrm{~S}^{6+}$ & 0.001 & 0.000 & 0.000 & 0.000 & 0.000 & 0.000 & 0.007 & 0.000 & 0.000 & 0.000 & 0.000 \\
\hline$\Sigma$ & 3.000 & 3.000 & 3.000 & 3.000 & 3.000 & 3.000 & 3.000 & 3.000 & 3.000 & 3.000 & 3.000 \\
\hline $\mathrm{Cl}^{-}$ & 1.090 & 1.104 & 1.064 & 1.050 & 1.136 & 1.118 & 1.124 & 1.092 & 1.036 & 1.092 & 1.085 \\
\hline$m$
\end{tabular}

mean - average of 10 analyses; calculated empirical formulas are based on sum of $(A s+P+V+S)=3$ apfu 
quantitatively, but their contents were below the detection limit (ca. $0.03-0.05$ wt. \% for individual elements). Raw intensities were converted to the concentrations of oxides using automatic "PAP" matrix-correction software (Pouchou, Pichoir 1985). The As distribution map was acquired on the same electron microprobe using LTAP crystal, AsL $\beta$ line, $25 \mathrm{kV}$ acceleration voltage, $40 \mathrm{nA}$ beam current, $1 \mu \mathrm{m}$ beam diameter and 512 x 512 resolution.

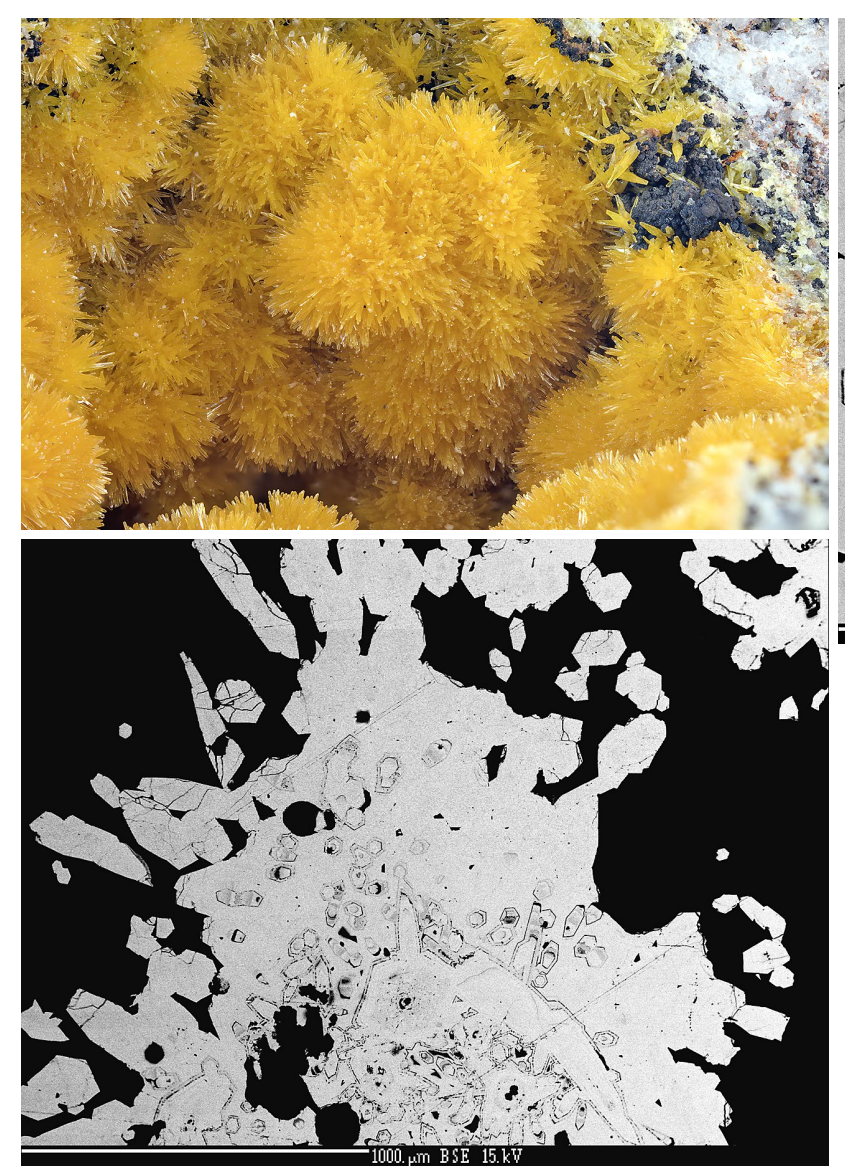

\section{Results}

Various morphological varieties of minerals of mimetite-pyromorphite series were observed at the Guatomo mine. Following six samples representing the different morphologies, colours as well as various geological environments/host rocks were studied:

Sample M1 is rich group of lustrous, yellow-orange to orange, short to long-prismatic crystals up to $1 \mathrm{~cm}$

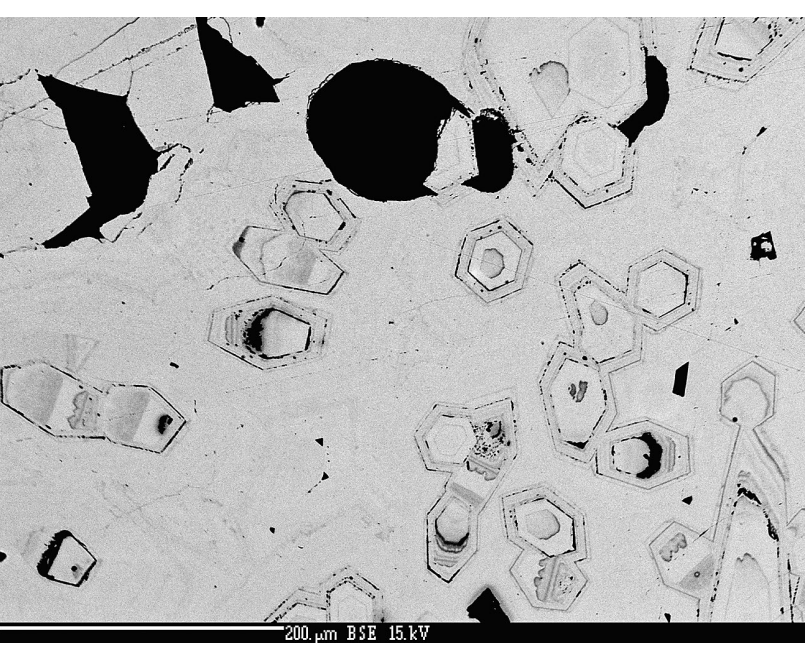

Fig. 11 Hemispherical aggregates of As-enriched pyromorphite (sample M3). Field of view is $14 \mathrm{~mm}$. Photo by P. Škácha.

Fig. 12 Chemically zonal aggregates of As-enriched pyromorphite (sample M3). BSE image by Z. Dolníček.

Fig. 13 Detail on sector to oscillatory chemical zoning in sample M3. BSE image by Z. Dolníček.

Table 3 Chemical composition of sample M3 (wt.\%).

\begin{tabular}{lrrrrrrrrrrr}
\hline & mean & 1 & 2 & 3 & 4 & 5 & 6 & 7 & 8 & 9 & 10 \\
\hline $\mathrm{CaO}$ & 0.89 & 0.17 & 0.08 & 0.72 & 0.19 & 0.14 & 1.21 & 0.98 & 0.15 & 4.00 & 1.28 \\
$\mathrm{PbO}$ & 79.11 & 79.80 & 79.15 & 78.52 & 81.24 & 79.66 & 79.24 & 79.44 & 79.80 & 75.43 & 78.86 \\
$\mathrm{P}_{2} \mathrm{O}_{5}$ & 12.40 & 10.79 & 10.14 & 11.80 & 13.22 & 11.20 & 13.24 & 12.92 & 11.32 & 15.39 & 13.98 \\
$\mathrm{As}_{2} \mathrm{O}_{5}$ & 5.43 & 7.30 & 8.66 & 6.21 & 4.47 & 6.79 & 4.43 & 4.78 & 6.70 & 1.57 & 3.41 \\
$\mathrm{~V}_{2} \mathrm{O}_{5}$ & 0.07 & 0.21 & 0.15 & 0.00 & 0.06 & 0.09 & 0.00 & 0.00 & 0.20 & 0.00 & 0.00 \\
$\mathrm{SO}_{3}$ & 0.01 & 0.00 & 0.00 & 0.00 & 0.00 & 0.00 & 0.00 & 0.04 & 0.00 & 0.00 & 0.04 \\
$\mathrm{Cl}$ & 2.78 & 2.65 & 2.79 & 2.83 & 2.89 & 2.67 & 2.89 & 2.80 & 2.69 & 2.68 & 2.95 \\
$\mathrm{O}=\mathrm{Cl}$ & -0.63 & -0.60 & -0.63 & -0.64 & -0.65 & -0.60 & -0.65 & -0.63 & -0.61 & -0.60 & -0.67 \\
\hline total & 100.07 & 100.32 & 100.34 & 99.44 & 101.42 & 99.95 & 100.36 & 100.33 & 100.25 & 98.47 & 99.85 \\
\hline $\mathrm{Ca}^{2+}$ & 0.214 & 0.042 & 0.019 & 0.175 & 0.045 & 0.034 & 0.288 & 0.234 & 0.036 & 0.928 & 0.301 \\
$\mathrm{~Pb}^{2+}$ & 4.771 & 4.923 & 4.838 & 4.791 & 4.835 & 4.914 & 4.731 & 4.764 & 4.875 & 4.398 & 4.666 \\
\hline$\Sigma$ & 4.985 & 4.965 & 4.858 & 4.965 & 4.880 & 4.948 & 5.019 & 4.998 & 4.912 & 5.327 & 4.968 \\
\hline $\mathrm{P}^{5+}$ & 2.352 & 2.093 & 1.949 & 2.264 & 2.475 & 2.173 & 2.486 & 2.437 & 2.175 & 2.822 & 2.602 \\
$\mathrm{As}^{5+}$ & 0.636 & 0.875 & 1.028 & 0.736 & 0.517 & 0.814 & 0.514 & 0.557 & 0.795 & 0.178 & 0.392 \\
$\mathrm{~V}^{5+}$ & 0.011 & 0.032 & 0.023 & 0.000 & 0.009 & 0.014 & 0.000 & 0.000 & 0.030 & 0.000 & 0.000 \\
$\mathrm{~S}^{6+}$ & 0.001 & 0.000 & 0.000 & 0.000 & 0.000 & 0.000 & 0.000 & 0.007 & 0.000 & 0.000 & 0.007 \\
\hline$\Sigma$ & 3.000 & 3.000 & 3.000 & 3.000 & 3.000 & 3.000 & 3.000 & 3.000 & 3.000 & 3.000 & 3.000 \\
\hline $\mathrm{Cl}^{-}$ & 1.057 & 1.029 & 1.074 & 1.087 & 1.083 & 1.037 & 1.086 & 1.057 & 1.035 & 0.984 & 1.099 \\
\hline mean - average of 10 analyses; calculated empirical formulas are based on sum of (As+P+V+S) 3 apfu &
\end{tabular}

mean - average of 10 analyses; calculated empirical formulas are based on sum of $(A s+P+V+S)=3$ apfu 
in size (Fig. 5), exhibiting the forms $\{0001\}$ and $\{10-10\}$. This type occurs in fractures of hydrothermal quartz veins crosscutting strongly altered granites, mostly in the central part of the Guatomo mine pit. Minor manganese

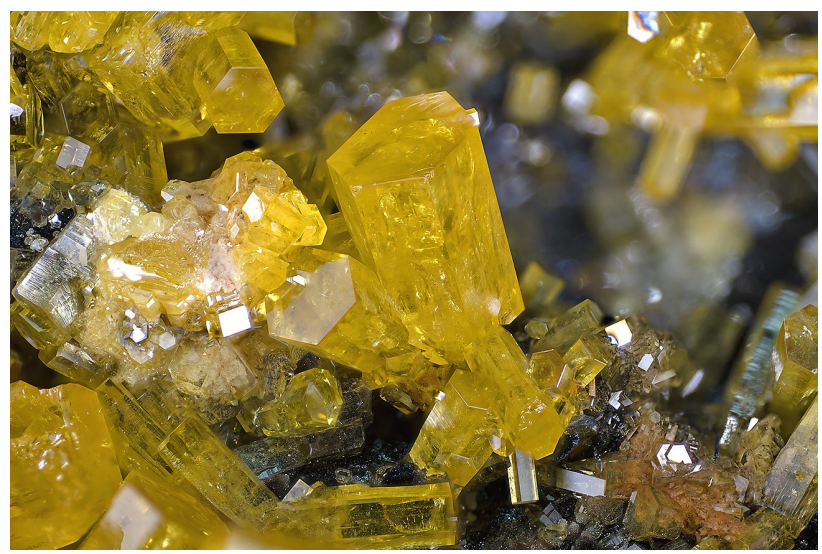

Fig. 14 Hexagonal long-prismatic crystals of mimetite (sample M4). Field of view is $12 \mathrm{~mm}$. Photo by P. Škácha.

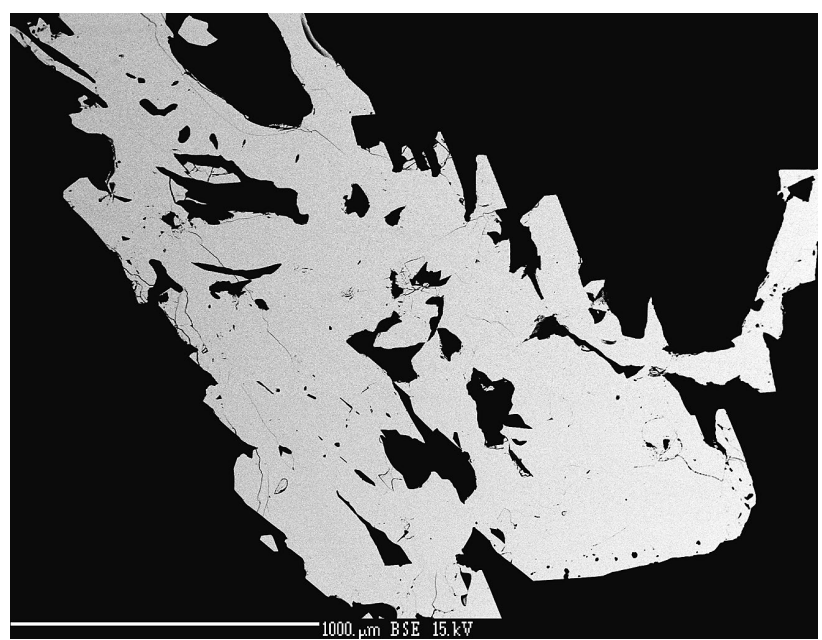

Fig. 15 Cross-section through chemically homogenous crystals of mimetite (sample M4). BSE image by Z. Dolníček. oxides are occasionally associated with this type of minerals of the mimetite-pyromorphite series.

No chemical zoning was observed in sample M1 (Fig. 6). The chemical composition of sample M1 (Tab. 1, Fig. 7) is close to the end member mimetite. Only negligible amounts of $\mathrm{Ca}$ (up to $0.01 \mathrm{apfu}$ ) as well as $\mathrm{P}$, $\mathrm{S}$ (both up to $0.03 \mathrm{apfu}$ ) and $\mathrm{V}$ (up to $0.02 \mathrm{apfu}$ ) were detected. The mean ( $n=10$ analyses) empirical formula of studied mimetite based on $(\mathrm{As}+\mathrm{P}+\mathrm{V}+\mathrm{S})=3$ apfu is $\mathrm{Pb}_{5.26}\left[\left(\mathrm{AsO}_{4}\right)_{2.98}\left(\mathrm{PO}_{4}\right)_{0.01}\left(\mathrm{SO}_{4}\right)_{0.01}\right]_{\Sigma 3.00} \mathrm{Cl}_{1.16}$

Sample M2 is represented by yellow-orange to bright orange, rich crystalline coatings and radial aggregates, which are developed in fractures of subhorizontal quartz vein hosted in altered granite (Fig. 3) and located in the central part of the Guatomo mine pit. Coatings and aggregates consisting of individual, spindle to barrel-shaped long-prismatic crystals up to $4 \mathrm{~mm}$ in size (Fig. 8).

This sample surprisingly shows no chemical zoning in BSE (Fig. 9) even when high beam currents are used (i.e., $40 \mathrm{nA}$ ), but differences in distribution of As were clearly observed in quantitative X-ray map (Fig. 10). It has quite variable chemical composition (Tab. 2, Fig. 7) ranging from $\mathrm{P}$-enriched mimetite (with 0.38 apfu of $\mathrm{P}$ ) up to As-rich pyromorphite (with 0.82 apfu of As). Minor amounts of $\mathrm{Ca}$ (up to $0.02 \mathrm{apfu}$ ), $\mathrm{V}$ and $\mathrm{S}$ (both up to 0.01 apfu) are also present. The average $(n=10)$ empirical formula of this sample is $\mathrm{Pb}_{5.05} \mathrm{Ca}_{0.01}\left[\left(\mathrm{AsO}_{4}\right)_{1.84}\left(\mathrm{PO}_{4}\right)_{1.16}\right]_{\Sigma 3.00}$ $\mathrm{Cl}_{1.09}$

Sample M3 is lemon-yellow to orange, hemispherical aggregate up to $5 \mathrm{~mm}$ in size, which consists of acicular, long-prismatic crystals up to $1 \mathrm{~mm}$ in length (Fig. 11). This type is rare and it occurs in small pockets and fractures developed directly in strongly altered granite, very close to the contact with gossan at the upper part of the pit.

Sample M3 shows weak sector to oscillatory chemical zoning in BSE (Fig. 12, 13) and compositionally it corresponds to As-enriched pyromorphite (Tab. 3, Fig. 7) with As content ranging from 0.18 to $1.03 \mathrm{apfu}$. Increased amounts of $\mathrm{Ca}$ (up to $0.93 \mathrm{apfu}$ ) as well as minor contents of $\mathrm{V}$ (up to $0.03 \mathrm{apfu}$ ) and S (up to $0.01 \mathrm{apfu}$ ) were detected. Calculated empirical formula (average of 10 analyses) is corresponding to $\mathrm{Pb}_{4.77} \mathrm{Ca}_{0.21}\left[\left(\mathrm{PO}_{4}\right)_{2.35}\right.$ $\left.\left(\mathrm{AsO}_{4}\right)_{0.64}\left(\mathrm{VO}_{4}\right)_{0.01}\right]_{\Sigma 3.00} \mathrm{Cl}_{1.06}$.

Table 4 Chemical composition of sample M4 (wt.\%).

\begin{tabular}{lrrrrrrrrrrr}
\hline & mean & 1 & 2 & 3 & 4 & 5 & 6 & 7 & 8 & 9 & 10 \\
\hline $\mathrm{CaO}$ & 0.01 & 0.03 & 0.03 & 0.00 & 0.00 & 0.00 & 0.00 & 0.00 & 0.00 & 0.00 & 0.00 \\
$\mathrm{PbO}$ & 75.27 & 74.89 & 75.27 & 74.98 & 75.73 & 75.27 & 75.32 & 75.29 & 75.13 & 75.57 & 75.22 \\
$\mathrm{P}_{2} \mathrm{O}_{5}$ & 0.01 & 0.00 & 0.07 & 0.00 & 0.00 & 0.00 & 0.00 & 0.00 & 0.03 & 0.02 & 0.00 \\
$\mathrm{As}_{2} \mathrm{O}_{5}$ & 22.04 & 21.56 & 21.84 & 21.81 & 22.54 & 22.21 & 22.32 & 22.23 & 22.24 & 22.01 & 21.66 \\
$\mathrm{SO}_{3}$ & 0.01 & 0.07 & 0.00 & 0.00 & 0.00 & 0.00 & 0.00 & 0.00 & 0.00 & 0.04 & 0.00 \\
$\mathrm{Cl}$ & 2.60 & 2.30 & 2.71 & 2.67 & 2.59 & 2.63 & 2.64 & 2.61 & 2.61 & 2.61 & 2.63 \\
$\mathrm{O}=\mathrm{Cl}$ & -0.59 & -0.52 & -0.61 & -0.60 & -0.58 & -0.59 & -0.60 & -0.59 & -0.59 & -0.59 & -0.59 \\
\hline total & 99.35 & 98.33 & 99.31 & 98.86 & 100.28 & 99.52 & 99.68 & 99.54 & 99.42 & 99.66 & 98.92 \\
\hline $\mathrm{Ca}^{2+}$ & 0.002 & 0.009 & 0.008 & 0.000 & 0.000 & 0.000 & 0.000 & 0.000 & 0.000 & 0.000 & 0.000 \\
$\mathrm{~Pb}^{2+}$ & 5.266 & 5.340 & 5.295 & 5.310 & 5.190 & 5.235 & 5.212 & 5.231 & 5.207 & 5.282 & 5.364 \\
\hline$\Sigma$ & 5.268 & 5.349 & 5.304 & 5.310 & 5.190 & 5.235 & 5.212 & 5.231 & 5.207 & 5.282 & 5.364 \\
\hline $\mathrm{P}^{5+}$ & 0.003 & 0.000 & 0.015 & 0.000 & 0.000 & 0.000 & 0.000 & 0.000 & 0.007 & 0.004 & 0.000 \\
$\mathrm{As}^{5+}$ & 2.995 & 2.986 & 2.984 & 3.000 & 3.000 & 3.000 & 3.000 & 3.000 & 2.993 & 2.988 & 3.000 \\
$\mathrm{~S}^{6+}$ & 0.002 & 0.014 & 0.000 & 0.000 & 0.000 & 0.000 & 0.000 & 0.000 & 0.000 & 0.008 & 0.000 \\
\hline$\Sigma$ & 3.000 & 3.000 & 3.000 & 3.000 & 3.000 & 3.000 & 3.000 & 3.000 & 3.000 & 3.000 & 3.000 \\
\hline $\mathrm{Cl}^{-}$ & 1.145 & 1.033 & 1.200 & 1.190 & 1.117 & 1.152 & 1.150 & 1.142 & 1.139 & 1.148 & 1.181 \\
\hline
\end{tabular}

mean - average of 10 analyses; calculated empirical formulas are based on sum of $(A s+P+S)=3$ apfu 
Sample M4 represents lustrous and gemmy, lemon-yellow to yellow-orange hexagonal long-prismatic crystals up $1 \mathrm{~cm}$ in size (Fig. 14), occasionally showing also pyramidal faces and slightly skeletal terminations. This classic type occurs as rich crystalline coatings in fractures of strongly altered and limonitised granite in the central part of the Guatomo mine pit (also called as philipsbornite trench by Sacchi (2017)). Associated minerals are black to iridescent coatings of $\mathrm{Pb}-\mathrm{Mn}$ oxides and microcrystalline coatings of minerals of the philipsbornite-segnitite series.

Chemical composition of the sample M4 is very close to the end member mimetite (Tab. 4, Fig. 7), it shows no chemical zoning in BSE (Fig. 15) and except of Pb, As and $\mathrm{Cl}$, only very minor amounts of $\mathrm{Ca}$ (up to 0.01 apfu), P (up to $0.02 \mathrm{apfu}$ ) and S (up to $0.01 \mathrm{apfu}$ ) were detected. The average $(n=10)$ empirical formula based on $(\mathrm{As}+\mathrm{P}+\mathrm{V}+\mathrm{S})=3$ apfu for this sample is $\mathrm{Pb}_{527}$ $\left(\mathrm{AsO}_{4}\right)_{3.00} \mathrm{Cl}_{1,15}$.

Sample $\mathbf{M} 5$ is another classic type represented by lustrous, pale-yellow to lemon-yellow or yellowish-orange, mostly short-prismatic to tabular crystals reaching up to $2.5 \mathrm{~cm}$ in size (Fig. 16), which are often strongly skeletal. They form rich groups filling the irregular pockets in porous limonitic gossan (Fig. 4) at the central as well as upper part of the pit. The only associated mineral is cerussite.

This sample is chemically homogenous in BSE (Fig. 17) and it corresponds to mimetite (Tab. 5, Fig. 7) with minor contents of Ca (up to $0.01 \mathrm{apfu}$ ), P (up to $0.18 \mathrm{apfu}$ ) and S (up to $0.01 \mathrm{apfu}$ ). Calculated empirical formula (average of 10 analyses) is $\mathrm{Pb}_{5.24} \mathrm{Ca}_{0.01}$ $\left[\left(\mathrm{AsO}_{4}\right)_{2.94}\left(\mathrm{PO}_{4}\right)_{0.06}\right]_{\Sigma 3.00} \mathrm{Cl}_{1.16}$.

Sample M6 is represented by rich groups and aggregates of lustrous, orange to orange-brown, barrel-shaped campylite-style crystals up to $1 \mathrm{~cm}$ (Fig. 18) as well as up to $7 \mathrm{~cm}$ thick massive veins developed in fractures of the gossan at the upper part of the Guatomo mine pit. Other associated supergene minerals are white to grey, slightly etched reticulated aggregates of cerussite up to $2 \mathrm{~cm}$ and black microcrystals of plattnerite, both growing on aggregates of minerals of the mimetite-pyromorphite series.
Sample M6 shows weak irregular chemical zoning (Fig. 19) and it corresponds to As-enriched pyromorphite (Tab. 6, Fig. 7) with As content ranging from 0.32 to 0.80 apfu. Minor amounts of $\mathrm{Ca}(0.04 \mathrm{apfu})$ as well as $\mathrm{V}$ and $\mathrm{S}$ (both reaching only up to $0.01 \mathrm{apfu}$ ) were detected. The average $(n=10)$ empirical formula of this sample is $\mathrm{Pb}_{4.92} \mathrm{Ca}_{0.02}\left[\left(\mathrm{PO}_{4}\right)_{2.34}\left(\mathrm{AsO}_{4}\right)_{0.66}\right]_{\Sigma 3.00} \mathrm{Cl}_{1.07}$.

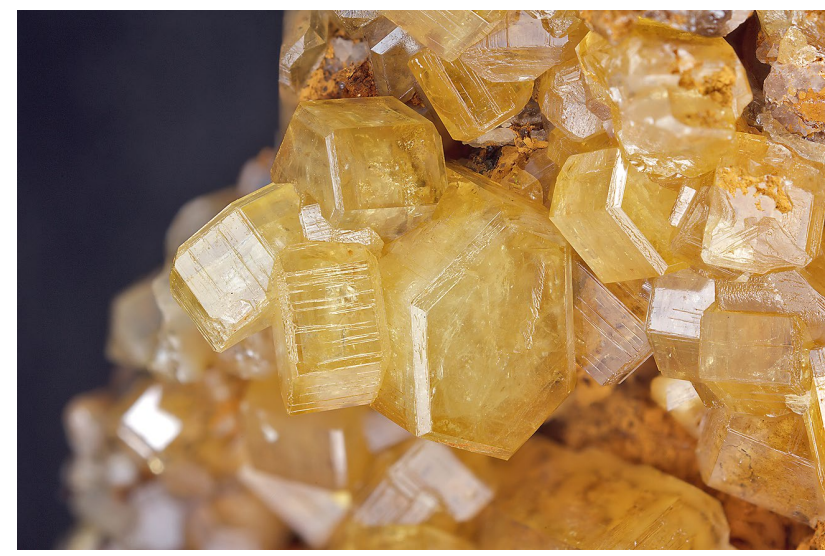

Fig. 16 Short-prismatic crystals of mimetite (sample M5). Field of view is $19 \mathrm{~mm}$. Photo by P. Škácha.

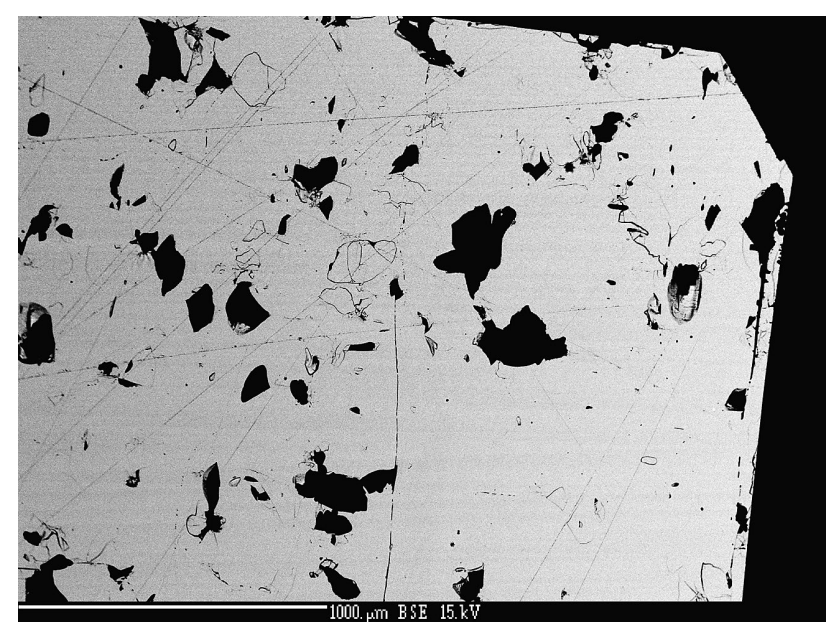

Fig. 17 Homogenous crystal of mimetite (sample M5). BSE image by Z. Dolníček.

Table 5 Chemical composition of sample M5 (wt.\%).

\begin{tabular}{|c|c|c|c|c|c|c|c|c|c|c|c|}
\hline & mean & 1 & 2 & 3 & 4 & 5 & 6 & 7 & 8 & 9 & 10 \\
\hline $\mathrm{CaO}$ & 0.03 & 0.03 & 0.04 & 0.03 & 0.00 & 0.04 & 0.04 & 0.04 & 0.04 & 0.00 & 0.00 \\
\hline $\mathrm{PbO}$ & 75.74 & 75.60 & 75.94 & 75.62 & 75.59 & 75.31 & 75.88 & 75.85 & 76.16 & 75.66 & 75.78 \\
\hline $\mathrm{P}_{2} \mathrm{O}_{5}$ & 0.29 & 0.83 & 0.09 & 0.05 & 0.01 & 0.27 & 0.34 & 0.39 & 0.36 & 0.13 & 0.46 \\
\hline $\mathrm{As}_{2} \mathrm{O}_{5}$ & 21.83 & 20.90 & 21.90 & 22.25 & 22.68 & 22.03 & 21.82 & 21.57 & 21.38 & 21.88 & 21.91 \\
\hline $\mathrm{SO}_{3}$ & 0.01 & 0.00 & 0.00 & 0.00 & 0.00 & 0.00 & 0.04 & 0.06 & 0.04 & 0.00 & 0.00 \\
\hline $\mathrm{Cl}^{\circ}$ & 2.66 & 2.72 & 2.68 & 2.61 & 2.62 & 2.65 & 2.72 & 2.65 & 2.67 & 2.67 & 2.63 \\
\hline $\mathrm{O}=\mathrm{Cl}$ & -0.60 & -0.61 & -0.60 & -0.59 & -0.59 & -0.60 & -0.61 & -0.60 & -0.60 & -0.60 & -0.59 \\
\hline total & 99.97 & 99.47 & 100.05 & 99.97 & 100.31 & 99.70 & 100.23 & 99.96 & 100.05 & 99.74 & 100.19 \\
\hline $\mathrm{Ca}^{2+}$ & 0.007 & 0.008 & 0.011 & 0.008 & 0.000 & 0.011 & 0.011 & 0.011 & 0.011 & 0.000 & 0.000 \\
\hline $\mathrm{Pb}^{2+}$ & 5.240 & 5.250 & 5.321 & 5.231 & 5.144 & 5.178 & 5.226 & 5.257 & 5.342 & 5.290 & 5.167 \\
\hline$\Sigma$ & 5.247 & 5.258 & 5.332 & 5.239 & 5.144 & 5.189 & 5.237 & 5.268 & 5.353 & 5.290 & 5.167 \\
\hline$\overline{P^{5+}}$ & 0.064 & 0.181 & 0.020 & 0.011 & 0.002 & 0.058 & 0.074 & 0.085 & 0.079 & 0.029 & 0.099 \\
\hline $\mathrm{As}^{5+}$ & 2.934 & 2.819 & 2.980 & 2.989 & 2.998 & 2.942 & 2.919 & 2.903 & 2.913 & 2.971 & 2.901 \\
\hline $\mathrm{S}^{6+}$ & 0.003 & 0.000 & 0.000 & 0.000 & 0.000 & 0.000 & 0.008 & 0.012 & 0.008 & 0.000 & 0.000 \\
\hline$\Sigma$ & 3.000 & 3.000 & 3.000 & 3.000 & 3.000 & 3.000 & 3.000 & 3.000 & 3.000 & 3.000 & 3.000 \\
\hline $\mathrm{Cl}^{-}$ & 1.159 & 1.189 & 1.182 & 1.137 & 1.123 & 1.147 & 1.179 & 1.156 & 1.179 & 1.175 & 1.129 \\
\hline
\end{tabular}

mean - average of 10 analyses; calculated empirical formulas are based on sum of $(A s+P+S)=3$ apfu 


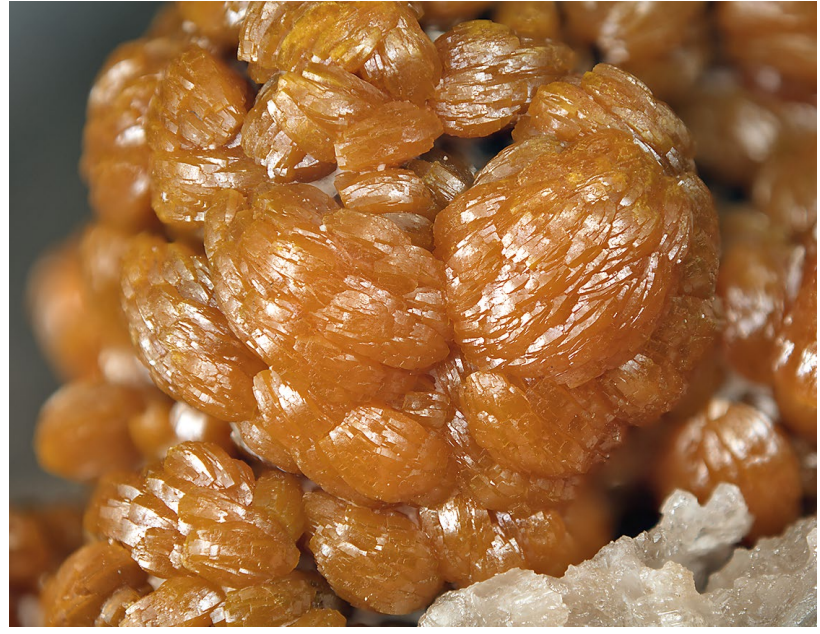

Fig. 18 Groups of barrel-shaped campylite-style crystals of As-enriched pyromorphite (sample M6) associated with cerussite. Field of view is $22 \mathrm{~mm}$. Photo by P. Škácha.

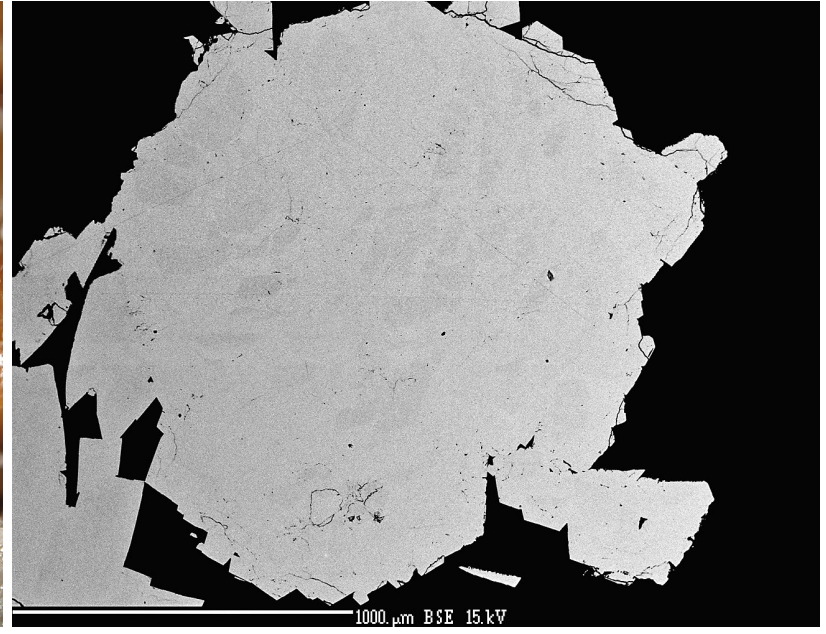

Fig. 19 Aggregate of As-enriched pyromorphite showing weak irregular chemical zoning (sample M6). BSE image by Z. Dolníček.

Table 6 Chemical composition of sample M6 (wt.\%).

\begin{tabular}{lrrrrrrrrrrr}
\hline & mean & 1 & 2 & 3 & 4 & 5 & 6 & 7 & 8 & 9 & 10 \\
\hline $\mathrm{CaO}$ & 0.08 & 0.10 & 0.04 & 0.08 & 0.08 & 0.11 & 0.17 & 0.12 & 0.03 & 0.04 & 0.03 \\
$\mathrm{PbO}$ & 79.82 & 79.24 & 79.84 & 79.84 & 80.11 & 80.12 & 80.36 & 79.19 & 79.68 & 79.69 & 80.15 \\
$\mathrm{P}_{2} \mathrm{O}_{5}$ & 12.12 & 11.48 & 12.24 & 11.56 & 11.84 & 12.69 & 14.08 & 12.07 & 11.41 & 12.13 & 11.68 \\
$\mathrm{As}_{2} \mathrm{O}_{5}$ & 5.53 & 5.90 & 5.27 & 6.38 & 6.15 & 4.70 & 2.75 & 5.76 & 6.72 & 5.47 & 6.16 \\
$\mathrm{~V}_{2} \mathrm{O}_{5}$ & 0.01 & 0.00 & 0.00 & 0.07 & 0.00 & 0.00 & 0.00 & 0.00 & 0.00 & 0.00 & 0.00 \\
$\mathrm{SO}_{3}$ & 0.00 & 0.00 & 0.05 & 0.00 & 0.00 & 0.00 & 0.00 & 0.00 & 0.00 & 0.00 & 0.00 \\
$\mathrm{Cl}$ & 2.78 & 2.78 & 2.78 & 2.79 & 2.72 & 2.74 & 2.75 & 2.78 & 2.78 & 2.84 & 2.87 \\
$\mathrm{O}=\mathrm{Cl}$ & -0.63 & -0.63 & -0.63 & -0.63 & -0.61 & -0.62 & -0.62 & -0.63 & -0.63 & -0.64 & -0.65 \\
\hline total & 99.71 & 98.86 & 99.59 & 100.09 & 100.28 & 99.74 & 99.49 & 99.29 & 99.98 & 99.54 & 100.25 \\
\hline $\mathrm{Ca}^{2+}$ & 0.019 & 0.025 & 0.010 & 0.019 & 0.019 & 0.026 & 0.040 & 0.029 & 0.007 & 0.010 & 0.007 \\
$\mathrm{~Pb}^{2+}$ & 4.900 & 5.000 & 4.901 & 4.896 & 4.886 & 4.901 & 4.858 & 4.835 & 4.885 & 4.903 & 4.936 \\
\hline$\Sigma$ & 4.919 & 5.025 & 4.911 & 4.915 & 4.905 & 4.928 & 4.898 & 4.864 & 4.892 & 4.913 & 4.944 \\
\hline $\mathrm{P}^{5+}$ & 2.339 & 2.277 & 2.364 & 2.230 & 2.271 & 2.441 & 2.678 & 2.317 & 2.200 & 2.346 & 2.263 \\
$\mathrm{As}^{5+}$ & 0.659 & 0.723 & 0.628 & 0.760 & 0.729 & 0.559 & 0.322 & 0.683 & 0.800 & 0.654 & 0.737 \\
$\mathrm{~V}^{5+}$ & 0.001 & 0.000 & 0.000 & 0.010 & 0.000 & 0.000 & 0.000 & 0.000 & 0.000 & 0.000 & 0.000 \\
$\mathrm{~S}^{6+}$ & 0.001 & 0.000 & 0.008 & 0.000 & 0.000 & 0.000 & 0.000 & 0.000 & 0.000 & 0.000 & 0.000 \\
\hline$\Sigma$ & 3.000 & 3.000 & 3.000 & 3.000 & 3.000 & 3.000 & 3.000 & 3.000 & 3.000 & 3.000 & 3.000 \\
\hline $\mathrm{Cl}^{-}$ & 1.075 & 1.103 & 1.073 & 1.075 & 1.043 & 1.054 & 1.045 & 1.067 & 1.071 & 1.102 & 1.114 \\
\hline $\mathrm{mean}$ & & & & & & & & & & &
\end{tabular}

mean - average of 10 analyses; calculated empirical formulas are based on sum of $(\mathrm{As}+\mathrm{P}+\mathrm{V}+\mathrm{S})=3$ apfu

\section{Conclusions}

The chemical composition of six morphologically different samples of minerals of mimetite-pyromorphite series from the Guatomo mine was studied in detail. This study revealed than not only mimetite, but also pyromorphite is present at the Guatomo mine and wide compositional variability was documented ranging from the nearly end member mimetite (samples M1, M4 and M5), through $\mathrm{P}$-enriched mimetite and As-rich pyromorphite (sample M2) up to As-enriched pyromorphite (sample M3 and M6).

\section{Acknowledgements}

The authors wish to thank to Pavel Škácha for the microphotography of studied samples and Jana Ulmanová for assistance during microprobe work. This study was financially supported by the Ministry of Culture of the Czech Republic (long-term project DKRVO 20192023/1.I.b; National Museum, 00023272).

\section{References}

Bode R (1998) Sicher Weltklasse: die Mimetesite aus Thailand. Mineral Welt 9(3): 43-44

Brown GF, Buravas S, Charaljavanaphet J, Jalichandra P, JOHNSTON WD, SREshtaputra V, TAYLOR GC (1951) Geologic Reconnaissance of the Mineral Deposits of Thailand. Geological Survey Bulletin 984, 1-197

Goodwin P, VIMolset S (1981) Mines \& Mineral Deposits of Thailand. Paul F. Scholla \& Associates, Bangkok, Thailand, 1-227

KING P (2007) Chinese enterprise and Malay power: Nineteenth-Century Central Malaya from a Regional Perspective. Chin South Diasp Stud 1: 97-105

MALAYSIAN-ThAI WORKING GROUP (2009) Geology of the Pengkalan Hulu-Betong Transect area along the Malaysia -Thailand border. Geological Papers Vol. 7, Minerals and Geoscience Department Malaysia, Kuala Lumpur, 1-84 
NATCHAKUNLASAP N (2004) Distribution and sources of heavy metals in stream sediments in Tum Talu watershed, Bunnung Sata, Yala, Southern Thailand. MSc. thesis, Chulalongkorn University, Bangkok, 1-101

PouchOU JL, PICHOIR F (1985) "PAP" ( $\varphi \rho Z)$ procedure for improved quantitative microanalysis. In: Microbeam Analysis (J. T. Armstrong, ed.). San Francisco Press, San Francisco, 104-106

RIDD MF, BARBER AJ, Crow MJ (2011) The Geology of Thailand. The Geological Society, London, 1-472

SACCHI MP (2017) The Guatomo („Hat Yai“) mine near Tham Thalu, Bannang Sata District, Yala Province, Thailand. Mineral Rec 48(6): 731-749
SUTHAKORN P (1992) The distribution of tin and associated minerals in Thailand. In: National Conference on Geologic resources of Thailand: Potential for Future Development. Department of Mineral Resources, Bangkok, 450-486

Whitbread-Abrutat PH, Paijitprapapon A, Charoenchaisri $P$ (1999) Treatment of arsenic-contaminated land in Thailand using diatomite: preliminary field site ivestigations. CSM technical Report, Camborne School of Mines, University of Exeter, Redruth, Cornwall, 1-64 